\title{
Character association and path analysis for yield and its related traits in finger millet (Eleusine coracana (L.) Gaertn) genotypes
}

\author{
Shivangi Negi ${ }^{1 *}$, Arun Bhatt ${ }^{2}$ and Vineet Kumar $^{2}$ \\ ${ }^{1}$ Department of Seed Science and Technology, VCSG University of Horticulture and Forestry, Bharsar \\ (Uttarakhand), INDIA \\ ${ }^{2}$ Department of Crop Improvement, VCSG Uttarakhand University of Horticulture and Forestry, Bharsar \\ (Uttarakhand), INDIA \\ *Corresponding author. E-mail: shivanginegi002@gmail.com
}

Received: November 11, 2016; Revised received: March 7, 2017; Accepted: August 8, 2017

\begin{abstract}
The present investigation was conducted during Kharif, 2014 at Research Block, Department of Crop Improvement, College of Forestry, Ranichauri Campus, V. C. S. G. Uttarakhand University of Horticulture and Forestry. The thirty-five diverse genotypes of finger millet, Eleusine coracana (L.) including three checks viz., PRM-1, PRM-2 and VL-149 laid out in Randomized Complete Block Design with replication. The data on 14 quantitative traits viz., days to 50 per cent flowering, days to maturity, plant height $(\mathrm{cm})$, flag leaf area $\left(\mathrm{cm}^{2}\right)$, peduncle length $(\mathrm{cm})$, number of leaves on main culm, number of productive tillers per plant, number of fingers per ear, finger length $(\mathrm{cm})$, ear length $(\mathrm{cm})$, biological yield per plant $(\mathrm{g})$, harvest index $(\%), 1000$ seed weight, grain yield per plant $(\mathrm{g})$ were collected randomly from 5 plants form each genotypes. Analysis of variance revealed highly significant differences among all thirty-five genotypes with a wide range of mean values for different characters. Grain yield per plant exhibited very strong positive association with biological yield per plant $(0.6196,0.6805)$, harvest index $(0.4370,0.3624)$, number of productive tillers per plant $(0.3950,0.4477), 1000$ seed weight $(0.3697,0.3972)$ and peduncle length $(0.2473,0.2694)$ at phenotypic and genotypic level. Path-coefficient analysis indentified biological yield per plant $(0.8983,1.1590)$ and harvest index $(0.7390,0.9162)$ as major direct contributors towards grain yield per plant at phenotypic and genotypic level. The characters identified above merit due consideration in formulating effective selection strategy in finger millet for developing high yielding varieties.
\end{abstract}

Keywords: Character association, Finger millet, Path-coefficient, Quantitative traits

\section{INTRODUCTION}

Finger millet (Eleusine coracana (L.) Gaertn. $2 n=4 x=36$ ) belongs to the family Poaceae, and is widely cultivated in the arid and semi-arid regions of the world. The term Eleusine is derived from Eleusis, an old epic city sacred to Demater, the greek deity presiding over agriculture. The term coracana is derived from kurukkan, the singhali name of the grain. The word Ragi is derived from Sanskrit word "Rajika" means red. Millets are small seeded grasses, and are distributed in about 10 genera and 20 species. It is cultivated mostly as a rainfed crop for its valued food grains, dry fodder and adaptability to wide range of geographical areas (Ulaganathan and Nirmalkumari, 2014)

Most of the small millets have their origin mainly in Asia and Africa. The most important domesticated areas are East Asia, India sub-continent and Ethiopian high lands of Africa. Small millets have long history of cultivation in India and grown a large number of millets in different parts of the country, so India is considered as hub for the small millets (Bist and Singh,
2009). In India, the total area under finger millet cultivation in year 2012 was $11,93,700$ hactare, with a production of 19,82,900 tons and productivity of about 16.61 quintals per hectare. Finger millet, locally know as mandua is the second major kharif crop in the state of Uttarakhand. The coverage area of finger millet in Uttarakhand was 122,200 hactares with a production of 153,900 tons and a productivity of 13.72 quintal per hectare in year 2013-14 (Directorate of Economics and Statistics, Ministry of Agriculture. G.O.I, 2013-14).

Ragi is commonly called as "Nutritious millet" as the grains are nutritionally superior to many cereals. It contains almost all the nutrients like protein (9.2 per cent), carbohydrates (76.32 per cent) and fat (1.29 per cent). It is very rich in minerals ( 2.70 per cent) such as calcium $(452 \mathrm{mg} / 1000 \mathrm{~g})$, iron $(3.90 \mathrm{mg} / 100 \mathrm{~g})$ and ash (3.90 per cent) which are the core ingredients of normal human diet (Pandey and Kumar, 2005). Being rich in protein, iron and calcium, finger millet severs as an important staple food for rural populations in developing tropical countries where calcium deficiency and anaemia are widespread (Owere et al., 2015). Finger millet is an excellent source of methionine, $\mathrm{Ca}, \mathrm{Fe}$, 
Mn. It is appreciated by the people; because it gets digested slowly there by furnishing energy required for hard work throughout the day. Many food preparations are made from ragi flour e.g. idlies, dosas, roties and uji. The protein of finger millet has been reported to possess a fairly high biological value, which is needed for the maintenance of nitrogen equilibrium of the body. It has crude fiber content (3-4 per cent) to supply energy for a long time after consumption and thus whole day sustenance, high cholesterol formation and intestinal cancer. Hence, people suffering from diabetics are advised to take finger millet and other small millets instead of rice (Malleshi and Hadimani, 1993). Expression of grain yield is complex and depends upon the interplay of several component attributes. A clear picture of contribution of each component in final expression of yield would emerge through the study of correlation and path coefficients which reveals different ways in which component attributes influence the yield. Hence, this study is aimed to analyze and determine the traits having interrelationship with grain yield utilizing the correlation and path analysis studies. Keeping in view the above facts, a field experiment was conducted to study correlation and path coefficient analysis for yield and its related traits in finger millet (Eleusine coracana (1.) Gaertn) germplsam at Ranichauri (Uttarakhand).

\section{MATERIALS AND METHODS}

The investigation was conducted during Kharif, 2014 at Research Block, Department of Crop Improvement, V. C. S. G. Uttarakhand University of Horticulture and Forestry, College of Forestry, Ranichauri Campus with thirty-five diverse genotypes of finger millet including three checks viz., PRM-1, PRM-2 and VL-149. Ranichauri campus situated at an altitude about $2100 \mathrm{~m}$ above mean sea level, lying between $35^{\circ} 15^{\prime} \mathrm{N}$ latitude and $78^{0} 30^{\prime}$ E longitude under mid hill zones of Utta- rakhand, India. It is situated humid and temperate type of climate with chilled winters. The average annual rainfall of $1230 \mathrm{~mm}$ was experienced a last 20 years. The accessions were obtained from Department of Crop Improvement, College of Forestry, Ranichauri, Project Coordinator Unit of All India Small Millet Improvement Project Bangalore and National Bureau of Plant Genetic Resources (NBPGR) New Delhi. The experiment was laid out in Randomized Complete Block Design with three replications. The soil of the experimental block of Crop Improvement Department was silty clay loam in texture having slightly acidic $\mathrm{pH}$ (5.5 to 5.6), low in available nitrogen $(210.0$ to $218 \mathrm{~kg}$ / ha) and available phosphorous (11.5 to $13.5 \mathrm{~kg} / \mathrm{ha})$ and rich in available potash $(408-418 \mathrm{~kg} / \mathrm{ha})$.

Observation were recorded from five randomly selected plants in each genotypes for fourteen characters viz., days to 50 per cent flowering, days to maturity, plant height $(\mathrm{cm})$, flag leaf area $\left(\mathrm{cm}^{2}\right)$, peduncle length $(\mathrm{cm})$, number of leaves on main culm, number of productive tillers per plant, number of fingers per ear, finger length $(\mathrm{cm})$, ear length $(\mathrm{cm})$, biological yield per plant $(\mathrm{g})$, harvest index $(\%)\{=$ grain yield/biological yield $\mathrm{X}$ $100\}, 1000$ seed weight $(\mathrm{g})$, grain yield per plant $(\mathrm{g})$ \{average yield of 5 randomly selected plants\}. The data collected for all quantitative characters were subjected to analysis of variance according to the method recommended by Cochran and Cox (1992).

\section{RESULTS AND DISCUSSION}

The mean value of the recorded data was subjected to analysis of variance (ANOVA) using the statistical analysis procedure of Cochran and Cox (1992). The result of analysis of variance of fourteen yield related traits for 35 genotypes is presented in Table 1 . The analysis of variance showed highly significant differences for all the characters indicating the presences of variability which can be exploited through selection. Substantial variations

Table 1. Analysis of variance for 14 characters in 35 finger millet (Eleusine coracana (L.) Gaertn.) genotypes.

\begin{tabular}{lcc}
\hline \multirow{2}{*}{ Character } & \multicolumn{2}{c}{ Mean sum of square (MSS) } \\
\cline { 2 - 3 } & Treatment \\
\hline Degree of freedom & 2 & 34 \\
Days of 50\% flowering & 0.63 & $170.09^{* *}$ \\
Days to maturity & 1.72 & $24.50^{* *}$ \\
Plant height (cm) & 19.82 & $227.16^{* *}$ \\
Flag leaf area $\left(\mathrm{cm}^{2}\right)$ & 0.75 & $32.33^{* *}$ \\
Peduncle length (cm) & 0.86 & $10.29^{* *}$ \\
No. of leaves on main culm & 0.03 & $2.33^{* *}$ \\
No. of productive tillers per plant & 0.08 & $1.63^{* *}$ \\
Fingers per ear & 0.27 & $1.29^{* *}$ \\
Finger length (cm) & 0.85 & $17.00^{* *}$ \\
Ear length (cm) & 0.42 & $17.08^{* *}$ \\
Biological yield per plant (g) & 6.65 & $387.25^{* *}$ \\
Harvest index (\%) & 7.88 & $38.15^{* *}$ \\
1000 seed weight $(\mathrm{g})$ & 0.003 & $0.16^{* *}$ \\
Grain yield per plant (g) & 0.47 & $7.58^{* *}$ \\
\hline
\end{tabular}

* Significant at $0.5 \%$ level; ** Significant at $0.01 \%$ level 
Shivangi Negi et al. / J. Appl. \& Nat. Sci. 9 (3): 1624 - 1629 (2017)

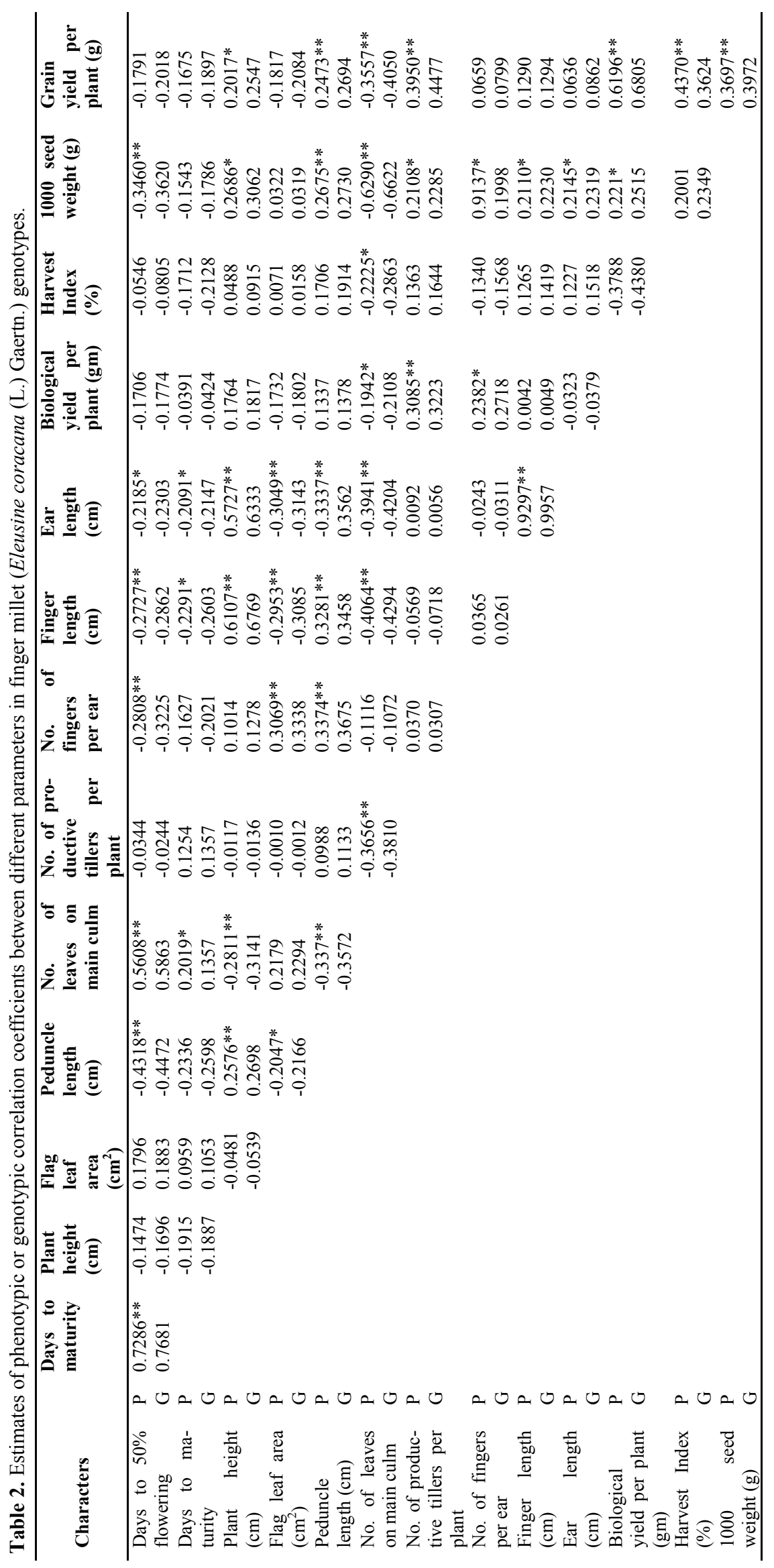


Shivangi Negi et al. / J. Appl. \& Nat. Sci. 9 (3): 1624 - 1629 (2017)

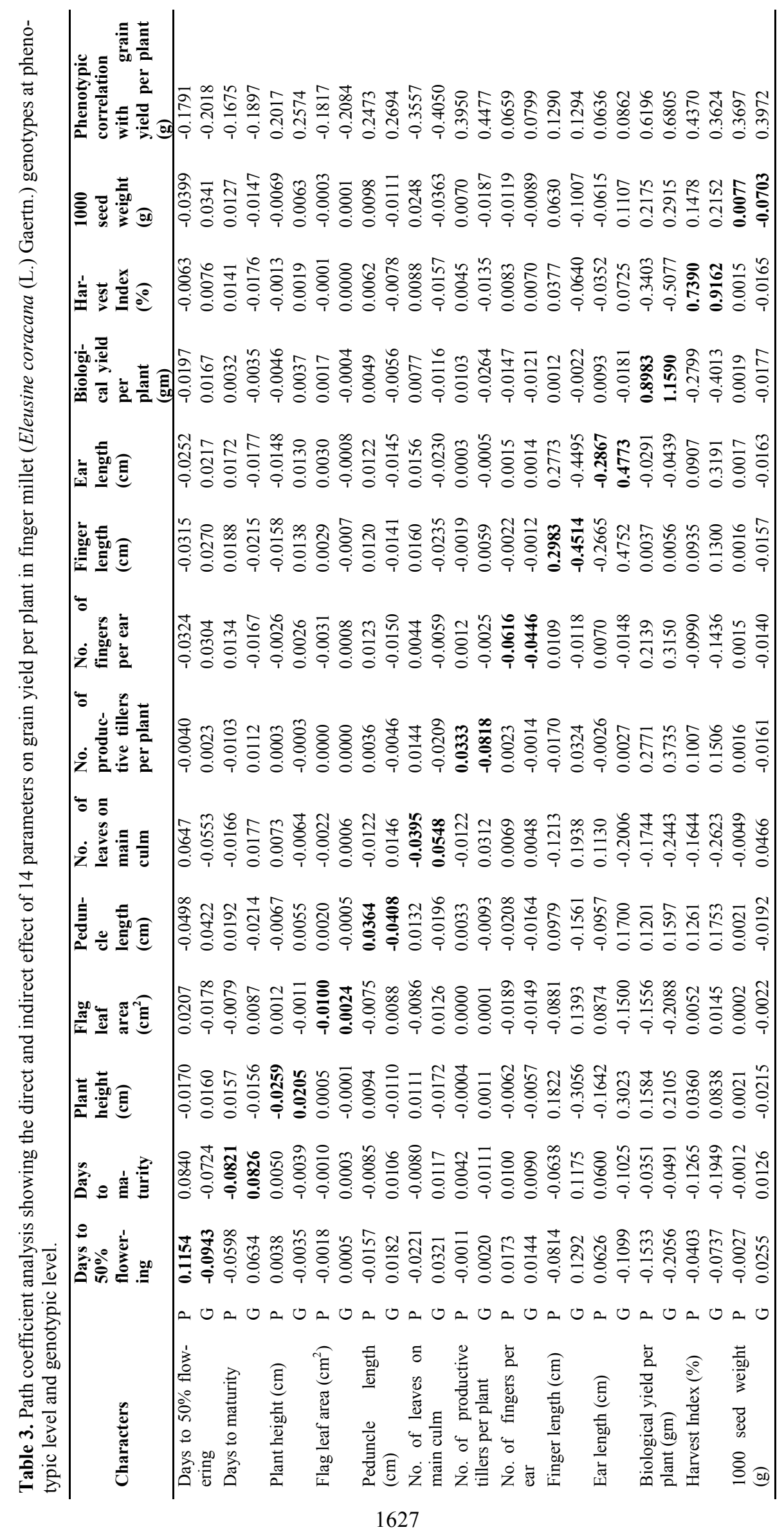


in finger millet have been also reported in previous study (Daba et al., 2000 and Kebere et al., 2006).

The grain yield in almost all the crops is referred to as super character which results from multiplicative interactions of several other characters that are termed as yield components. Therefore, identification of important yield components and information about their association with yield and also with each other is very useful for developing efficient breeding strategy for evolving high yielding variety. In this respect, the correlation coefficient which provides symmetrical measurement of degree of association between two variables or characters, help us in understanding the nature and magnitude of association among yield and yield components. The genotypic correlation coefficients between different characters were generally similar in sign and nature to the corresponding phenotypic correlation coefficients in the experiment. However, genotypic correlations were higher in magnitude than the corresponding phenotypic values. Misra et al. (2008); Ali et al. (2013) and Suryanarayana et al. (2014) also reported higher estimates of genotypic correlation than the corresponding phenotypic correlation coefficients between yield and yield components in finger millet.

In present study, a very strong positive association of grain yield per plant was observed at phenotypic and genotypic level with biological yield per plant $(0.6196$, $0.6805)$, harvest index $(0.4370,0.3624)$, number of productive tillers per plant $(0.3950,0.4477), 1000$ seed weight $(0.3697,0.3972)$ and peduncle length $(0.2473$, 0.2694) while plant height exhibited strong positive association at genotypic and phenotypic level (Table 2). Thus, present results are in consonance with Gowda (1996); Ravishankar (1996); Anantharaju and Meenakshiganeshan (2005); Kebere et al. (2006); Misra et al. (2008); Wolie et al. (2011) and Suryanarayana et al. (2014) in finger millet. Number of leaves on main culm was the only character which showed strong negative association with grain yield per plant at phenotypic as well as phenotypic level.

The phenotypic and genotypic correlation coefficients between important yield components varied from being significantly positive to significant negative besides being non-significant for many characters pairs. This reveals a high complete situation in attaining a proper balance between yield and its components in context of finger millet genotypes used in present study due to complexities that arise due to existence of strong negative and positive association between various characters in this, as well as in many other crops. Most of the correlation coefficients obtained in present study are in conformity with previous reports in finger millet (Kebere et al., 2006; Misra et al., 2008 and Suryanarayana et al., 2014).

Correlation study only provides information on the relationship and does not give an idea on the cause of this relation and sometimes information obtained is misleading with respect to identification of yield components.

Path coefficient analysis is a tool to partition the observed correlation coefficient in direct and indirect effects of yield components on grain yield to provide clear picture of character associations for formulating efficient selection strategy. Path analysis differs from simple correlations in that it points out the cause and their relative importance, whereas the latter measure simply the mutual association ignoring the causation. Path analysis is one which provides information on the cause of such association (Wright, 1921 and Dewey and $\mathrm{Lu}, 1959$ ). The results of various causes influencing grain yield (effect) are shown in Table 3 at the phenotypic and genotypic levels, respectively.

In present study, the path coefficient analysis was carried out at phenotypic as well as genotypic level. Biological yield per plant $(0.8983,1.1590)$ followed by harvest index $(0.7390,0.9162)$ exerted very high positive direct effects on grain yield per plant at both phenotypic as well as genotypic level. Finger length $(0.2983)$ and days to 50 per cent flowering (0.1154) also exhibited considerable positive direct effect on grain yield per plant at phenotypic level (Table 3). Thus, biological yield per plant and harvest index emerged as most important direct yield contributing characters. Hence, direct selection for these traits would be rewarding for yield improvement, which will also reduce the undesirable effects of the component traits studied. These characters have also been identified as major direct contributors towards grain yield in finger millet by earlier workers (Cauvery (1993); Pathe and Bhave (2001); Bedix et al., 2006; Wolie et al., 2011 and Kumar et al., 2014).

\section{Conclusion}

The study has provided crucial information on character association and path analysis in finger millet genotypes. It revealed that grain yield per plant exhibited very strong positive association with biological yield per plant $(0.6196,0.6805)$, harvest index $(0.4370$, $0.3624)$, number of productive tillers per plant $(0.3950,0.4477), 1000$ seed weight $(0.3697,0.3972)$ and peduncle length $(0.2473,0.2694)$ at phenotypic and genotypic level. Path-coefficient analysis indentified biological yield per plant $(0.8983,1.1590)$ and harvest index $(0.7390,0.9162)$ as major direct contributors towards grain yield per plant at phenotypic and genotypic level. Thus, there is an opportunity to bring about improvement of the crop yield through direct and indirect selection as well as improving of these characters through hybridization.

\section{REFERENCES}

Ali, K., Ramesh, B., Gangwar, L. K., Imran, M. and Kamboj, G. (2013). Variability, heritability and correlation among agro-morphological traits in Finger millet 
(Eleusine coracana (L.) Gaertn). Progress. Res, 8(1): 95-98.

Anantharaju, P. and Meenakshiganesan. (2005). Studies on correlation and path coefficient analysis of yield and yield contributing characters in Finger millet (Eleusine coracana (L.) Gaertn). Crop Res, 30(2): 227-230.

Bedix, M. R., Patil, H. S., Jangle, G. D. and Patil, V. S. (2006). Correlation and path analysis in finger millet (Eleusine coracana (L.) Gaertn). Crop Res, 31(2): 264268.

Bisht, B. S. and Singh, D. P. (2009). Agriculture in uttarakhand hills. Directorate of experimental station, $G$. B. Pant univ. of agri. and technology, Pantnagar. Pp 1117.

Cauvery, M. B. (1993). Variability for fodder yield, its component and grain yield in Indian and African collection of finger millet. M.Sc. (Agri) Thesis, University of Agricultural Sciences, Bangalore, India.

Cochran, W. G. and Cox, M. G. (1992). Experimental Design, New York, USA; John Wiley sons Inc. pp. 106117.

Daba, C. 2000. Variability and Association among Yield and Related Traits in Finger Millet [Eleusine coracana (L) Gaertn]. M.Sc. Thesis. Alemaya University.

Dewey, D. R. and Lu, K. R. (1959). A correlation and path coefficient analysis of component of crested wheat grass seed production. Agron. J, 56(4): 439-446.

Gowda, M. (1996). Genetic variability studies in African germplasm of finger millet (Eleusine coracana (L.) Gaertn). M.Sc. (Agri.) Thesis, University of Agricultural Sciences, Bangalore, India.

Kebere, B., Sripichitt, P., Wohgyai, W. and Hongtrakul, V. (2006). Genetic variation, heritability and path analysis in Ethiopian finger millet (Eleusine coracana (L.) Gaertn) landraces. Kasetsart J. (Natual Sci),40:322334.

Kumar, D., Tyagi, V. and Ramesh, B. (2014). Path coefficient analysis for yield and its contributing triats in finger millet. Int. J. of Adv. Res, 2(8): 235-240.
Malleshi, N. G. and Hadimani, N. A. (1993). Nutritional and technological characteristics of small millets and preparation of value-added products from them In: Advances in Small millet Praceeding of Second International Small Millet workshop, Bulawayo, Zimbabwe.

Misra, R. C., Sahu, P. K., Pradhan, B., Das, S. and Mishra, C. H. P. (2008). Character association, path-coefficient and selection indices in Finger millet (Eleusine coracana). Enviro. and Eco, 26(1): 166-170.

Owere, L., Tongoona, J., Derera, J. and Wanyera, N. (2015). Variability and traits relationships among finger millet accessions in Uganda. Uganda J. of Agri. Sci, 16(2): 161-176.

Pandey, P. K. and Kumar, G. S. (2005). Finger Millet: A Flair for Human Nutrition in Uttaranchal. Indian Farmers Digest, 38(9): 28-30.

Pathe, U. V. and Bhave, S. G. (2001). Correlation and path analysis in finger millet (Eleusine coracana (L.) Gaertn) genotypes. J. Soils. Crops, 10(30): 180-185.

Ravishankar, P. (1996). Evaluation of Zimbabwean germplasm of ragi (Eleusine coracana (L.) Gaertn). M.Sc. (Agri) Thesis. University of Agricultural Sciences, Bangalore, India.

Suryanarayana, L., Sekhar, D. and Rao, N. V. (2014). Inter relationship and cause-effect analysis in Finger millet (Eleusine coracana (L.) Gaertn) genotypes. Int. J. of Curr. Micro. and App. Sci, 3: 937-941.

Ulaganathan, V. and Nirmalakumari A. (2014). Genetic variability and correlation studies for quantitative traits in finger millet (Eleusine coracana (L.) Gaertn) germplasm. Int. Quarterly Jour. of Enviro. Sci, $5(6): 21-25$

Wolie, A. and Dessalegn, T. (2011). Correlation and path coefficient analyses of some yield related traits in Finger millet (Eleusine coracana (L.) Gaertn) germplasm in northwest Ethiopia. Indian J. of Agri. Res, 6(22): 50995105.

Wright, S. (1921). Correlation and causation. J. Agri. Sci, 50 (11): 807-815. 